\title{
Was Entick v Carrington a Landmark?
}

\section{Timothy Endicott}

\section{Introduction}

As the ship approaches the continent from the open sea, it will be good if some feature on the coastline gives an indication of the lie of the land, and a guide for the journey. A landmark is a guide to a landscape. ${ }^{1}$ The landscape that concerns us is English law in its diachronic aspect, and I will ask whether Entick $v$ Carrington gives us a guide to that landscape. The decision came in a remarkable decade when Lord Mansfield, Lord Camden and Sir William Blackstone (in their different fashions) were each contributing to the articulation of the basis of public powers. We may well hope to find a guide in Lord Camden's most deliberate effort at accounting for public power and its limits.

A judicial decision will give a guide to the landscape if it changed the law, so that understanding the decision will help us to understand how the law developed. And it may also be a landmark if the court's explanation of the law influenced later decisions (or explanations of the law by scholars and historians), or simply by virtue of the usefulness of the report of the decision for explaining the law today. I think, in fact, that the decision is a landmark in each of these three senses.

To put first things first, Entick $v$ Carrington made a significant change to the law. General warrants had already been held to be unlawful, so it may seem that the decision in Entick merely gave effect to precedents. But it is not so, and there is a reason for students today to learn about John Entick's case, although I wish they would also learn about the case of the historically much more important John Wilkes (and Lord Camden's rhetoric is just as high-flown in Wilkes $v$ Wood $^{2}$ as in Entick). Entick $v$ Carrington established that generality was not the real problem. The warrant to search John Entick's home and to seize his papers

\footnotetext{
${ }^{1}$ This usage seems to be a metaphor based on a landmark as a boundary stone: the King James Version translates Deuteronomy 27:17 as 'Cursed be he that removeth his neighbour's landmark.' See Oxford English Dictionary sub verb 'landmark'.

${ }^{2}$ Wilkes $v$ Wood (1763) Lofft 1, 98 ER 489.
} 
named him specifically. ${ }^{3}$ The problem with the warrant was that the Secretary of State could not lawfully authorise by warrant the search and seizure of property on suspicion of seditious libel.

Entick is a landmark not only in the development of the law of the constitution, but also in the development of a distinctively English mixture of judicial restraint and judicial creativity. A judge in a healthy legal system sees both restraint and creativity as duties; Lord Camden's decision is a model of the common law method of devising new ways of controlling public powers, while disclaiming any power to legislate and, in fact, claiming to abide by the 'ancient venerable edifice' of the constitution. The result was a practical reform that protected civil liberties, on the basis of a very conservative understanding of the constitution, according to which public authorities are limited by law, but have powers that are not specified by law. I will defend that understanding against the twenty-first-century idea that public authorities may do nothing except what the law expressly or impliedly authorises.

\section{Landmark Decisions}

A decision is sometimes called a 'landmark' vaguely to indicate that it is an important case, and sometimes because it is a case that a student ought to know about. Perhaps we can give the term some precision if we remember that we are talking about the common law. It changes as the judges change their approach. It is changed overnight by an authoritative decision based on new grounds and it changes as the judges reinterpret old cases or rediscover new grounds in old cases. A landmark-for the purposes of understanding the development of the common law-is a case that had an important impact on the development of the law.

So it seems very attractive to think that the primary meaning of a 'landmark' must involve an important change in the law. I think there is something to this. Yet you never find the judges saying that 'the common law has always been in favour of the defendant in a case like this until now, but we hereby change it'. We can illustrate this familiar ambivalence

\footnotetext{
${ }^{3}$ Although the warrant was very general as to the class of belongings of that particular person might be seized. On ways in which laws and orders can be general, see T Endicott, 'The Generality of Law' in L Duarte Almeida, A Dolcett and J Edwards (eds), Reading The Concept of Law (Oxford, Oxford University Press, 2013).
} 
about change in the common law by noting the cases that the justices of the UK Supreme Court have referred to as landmarks.

\section{A. Landmarks According to the UK Supreme Court}

Six decisions have been referred to as 'landmarks' by the Justices of the Supreme Court since its inauguration, ${ }^{4}$ and three are particularly interesting for our purposes. ${ }^{5}$

\section{i. Conway v Rimmer ${ }^{6}$}

This case is interesting because the House of Lords really did more or less say that they were changing the law as established in their decision on Crown privilege in Duncan $v$ Cammell Laird \& Co Ltd. ${ }^{7}$ Thus, Lord Reid considered that the Law Lords should learn from ' 25 years' experience since Duncan's case' and concluded:

[T] he House ought now to decide that courts have and are entitled to exercise a power and duty to hold a balance between the public interest, as expressed by a Minister, to withhold certain documents or other evidence, and the public interest in ensuring the proper administration of justice. ${ }^{8}$

Lord Morris agreed:

Though precedent is an indispensable foundation upon which to decide what is the law, there may be times when a departure from precedent is in the interests of justice and the proper development of the law. I have come to the conclusion that it is now right to depart from the decision in Duncan's case. ${ }^{9}$

Lord Upjohn agreed, too:

Times change ... the relation between Crown and subject becomes closer every day ... Then for 20 years the subject has been able to sue the Crown, and the increase in crime, motor accidents and the like have all led to a great increase in the number of cases where the Crown is asked to produce documents. So I think that in this field the courts are entitled from time to time to make a re-appraisal... ${ }^{10}$

\footnotetext{
${ }^{4}$ To June 2014.

${ }^{5}$ The others are St Helen's Smelting Co v Tipping (1865) 11 HL Cas 642 (law of nuisance), referred to in Coventry v Lawrence [2014] UKSC 13; Woolwich Equitable Building Society v Inland Revenue Commissioners [1993] AC 70 (recovery of moneys paid under a mistake of law), referred to in Test Claimants in the Franked Investment Income Group Litigation v Commissioners of Inland Revenue [2012] UKSC 19, 142; and Bankovic v UK (2001) 11 BHRC 435 (the extent of application of the European Convention on Human Rights), referred to in $R$ (on the application of Smith) $v$ Secretary of State for Defence [2010] UKSC 29 [48].

${ }^{6}$ Referred to as a landmark in In re A [2012] UKSC 60 [16].

${ }^{7}$ Duncan v Cammell Laird \& Co Ltd [1942] AC 624

${ }^{8}$ Conway v Rimmer [1968] AC 910, 951-52.

9 ibid 958 .

10 ibid 991-92.
} 
It is interesting that the judges saw the change that they were making in the case as a rather specific overruling of a particular decision. They were candid about departing from a precedent of their court. Yet they rather downplayed the fact that they were departing not just from one decision, but also from a deeply entrenched practice of the common law, and they were ambivalent about departing from the law itself. Lord Morris called precedent an 'indispensable foundation upon which to decide what is the law', suggesting somehow that by reversing the decision in Duncan, they might not be changing the law.

This ambivalence notwithstanding, let's take Conway $v$ Rimmer as our paradigm of a landmark: a decision in which the court of highest jurisdiction saw itself as changing something on important grounds of principle that changed the direction of the common law.

\section{ii. Anisminic}

The second case is Anisminic Ltd $v$ Foreign Compensation Commission. ${ }^{11}$ In $R$ (Lumba) $v$ Secretary of State for the Home Department ${ }^{12}$ and Eba $v$ Advocate General for Scotland, ${ }^{13}$ the Justices of the Supreme Court referred with implicit approval to Lord Diplock's dictum in In re Racal Communications $L t d^{14}$ that the decision in Anisminic was a 'legal landmark'.

Anisminic was an interesting and difficult case, in which no clear ratio emerges except that it is possible for an administrative tribunal to act without jurisdiction by virtue of a misinterpretation of the law. ${ }^{15}$ Lord Reid made it clear in his leading speech in Anisminic that some mistakes of law do and some do not take an administrative body outside its jurisdiction. Lord Diplock, instead, treated the decision as if it had been that an administrative tribunal necessarily acts without jurisdiction if it bases its decision on an error of law:

The break-through made by Anisminic [1969] 2 AC 147 was that, as respects administrative tribunals and authorities, the old distinction between errors of law that went to jurisdiction and errors of law that did not, was for practical purposes abolished. Any error of law that could be shown to have been made by them in the course of reaching their decision on matters of fact or of administrative policy would result in their having asked themselves the wrong question with the result that the decision they reached would be a nullity. ${ }^{16}$

\footnotetext{
${ }^{11}$ Anisminic Ltd v Foreign Compensation Commission [1969] 2 AC 147.

${ }^{12} R$ (Lumba) v Secretary of State for the Home Department [2011] UKSC 12 [304].

${ }^{13}$ Eba v Advocate General for Scotland [2011] UKSC 29 [34].

${ }^{14}$ In re Racal Communications Ltd [1981] AC 374, 382.

${ }^{15}$ For a discussion, see T Endicott, Administrative Law, 2nd edn (Oxford, Oxford University Press, 2011) 310-19.

${ }^{16}$ In re Racal Communications Ltd (n 14) 382.
} 
Lord Diplock wanted to call Anisminic in aid as authority for a new general judicial authority to quash decisions for error of law, and calling Anisminic a 'landmark' was part of his claim that it had made a major change in the law.

\section{iii. Home Office v Tariq}

In Home Office v Tariq, ${ }^{17}$ Lord Kerr, dissenting, called the decision of the majority in the same case a 'landmark':

The withholding of information from a claimant which is then deployed to defeat his claim is, in my opinion, a breach of his fundamental common law right to a fair trial ... This court's endorsement of a principle of non-disclosure ... is a landmark decision, marking a departure from the common law's long established commitment to this basic procedural right. In my view, the removal of that right may only be achieved by legislation and only then by unambiguous language that clearly has that effect. ${ }^{18}$

Lord Kerr viewed the majority as making a significant and retrograde change in the law; calling the majority's decision a 'landmark' was a way of expressing his reason for dissenting.

These anecdotes about landmarks are reminders that: (1) judges do not generally set out to identify the decision they are making as a landmark; (2) calling a decision a landmark while it is being made can be derogatory; and (3) calling a decision of the past a landmark tends to be part of a claim that the decision changed the law in a wise direction. The ambivalence about change tends to fall away when people call a decision of the past a 'landmark'.

\section{The Fame of Entick v Carrington}

Like the work of Sir William Blackstone, Lord Camden's decision in Entick has made more of a splash in the US than in the UK. Like habeas corpus, the doctrine in Entick was an element in the constitution that the American revolutionaries wanted to keep. In the first major case on the Fourth Amendment to the Constitution, the US Supreme Court justices presented Entick as the very model of a landmark:

$[\mathrm{H}]$ is great judgment on that occasion is considered as one of the landmarks of English liberty. It was welcomed and applauded by the lovers of liberty in the colonies, as well as in the mother country. It is regarded as one of the permanent monuments of the British Constitution, and is quoted as such by the English authorities on that subject down to the present time.

\footnotetext{
${ }^{17}$ Home Office v Tariq [2011] UKSC 35.

18 ibid [108].
} 
As every American statesmen, during our revolutionary and formative period as a nation, was undoubtedly familiar with this monument of English freedom, and considered it as the true and ultimate expression of constitutional law, it may be confidently asserted that its propositions were in the minds of those who framed the Fourth Amendment to the Constitution, and were considered as sufficiently explanatory of what was meant by unreasonable searches and seizures. ${ }^{19}$

In England, even though it is indeed a monument of the constitution, it is not evident that the decision in Entick had such a great impact. The damage awards in the other cases had already changed the political calculations, and in 1766, the House of Commons turned against the use of the warrants. I suppose that if Entick had been decided against the plaintiff, it would have become the Darnel's case of the eighteenth century and legislation would have had to follow.

I do not think that that Lord Camden's decision played a very fertile role as a precedent for further judicial developments in the law either. In the eighteenth century, there are some rather incidental citations in Brass Crosby's Case, ${ }^{20}$ Cooper $v$ Boot $^{21}$ and Warne $v$ Varley. ${ }^{22}$ In subsequent decades, it was sometimes cited for its holding that it is the publishing of a libel, and not mere possession of a libel in a drawer in your home, that was a crime. ${ }^{23}$ Or it is mentioned in discussions of the powers of secretaries of state, without really being needed, ${ }^{24}$ or is referred to only to be distinguished. ${ }^{25}$

But by the first half of the twentieth century, Entick was taken for granted as a pillar of the constitution, eg, in Keir and Lawson's case book:

The rules excluding the doctrine of State necessity and any appeal to the mere practice of a public authority played a very great part in Entick $v$ Carrington, which is perhaps the central case in English constitutional law ... If Entick $v$ Carrington has retained primary importance for the constitutional lawyer, it is because of the more general enunciations of principle which it contains. ${ }^{26}$

\footnotetext{
${ }^{19}$ Boyd v United States 116 US 616 (1886).

${ }^{20}$ Brass Crosby's Case (1771) 2 Blackstone W 754; 96 ER 441.

${ }^{21}$ Cooper v Boot (1785) 4 Douglas 339; 99 ER 911.

${ }^{22}$ Warne v Varley (1795) 6 Term Reports 443; 101 ER 639.

${ }^{23} \mathrm{eg}, R v$ Burdett (1820) 3 B \& A 717; 106 ER 823, 828.

${ }^{24} \mathrm{eg}$, Wilson v Reddall (1819) Gow 161, 171 ER 870, Harrison v Edwin Bush (1855) 5 El \& Bl 344; 119 ER 509.

${ }^{25} R v$ Watts (1830) 1 B \& Ad 166; 109 ER 749.

${ }^{26}$ DL Keir and FH Lawson, Cases in Constitutional Law, 4th edn (Oxford, Oxford University Press, 1954) 170
} 
It took pride of place with Lord Denning, not only in his judgment in the Rossminster case, ${ }^{27}$ but also as one of the landmark cases in a book he wrote late in his career, Landmarks in the Law, where he tells the story of Entick without adding much comment. ${ }^{28}$

I presume that the fame of Entick is partly due to Dicey, who used it in his explication of the rule of law. The first component of the rule of law, he said, is the principle that no is man punishable except for breach of the law established in the ordinary courts; the third is the principle that rights come from judicial decisions. The second is a version of the principle in Entick:

We mean in the second place, when we speak of the 'rule of law' as a characteristic of our country, not only that with us no man is above the law, but (what is a different thing) that here every man, whatever be his rank or condition, is subject to the ordinary law of the realm and amenable to the jurisdiction of the ordinary tribunals ... The Reports abound with cases in which officials have been brought before the Courts and made in their personal capacity liable to punishment or to the payment of damages for acts done in their official character but in excess of their lawful authority. A colonial governor, a secretary of state, a military officer, and all subordinates, though carrying out the commands of their official superiors, are as responsible for any act which the law does not authorise as is any private and unofficial person. ${ }^{29}$

After 'a secretary of state', Entick $v$ Carrington is footnoted. That is all the use that Dicey made of the case, and he did not quote Lord Camden. But this paragraph is the passage in Dicey that is actually read, and it has presented Entick to generations of lawyers as an exemplar of the rule of law.

Of course, others have used it as an exemplar. Before Dicey came along, Entick featured along with Leach $v$ Money and Wilkes $v$ Wood in EC Thomas' Leading Cases in Constitutional Law, ${ }^{30}$ which would run for 70 years to an eighth edition under Owen Hood Phillips in 1947. And today, Harlow and Rawlings call the series of general warrants cases

\footnotetext{
${ }^{27}$ Inland Revenue Commissioners ex p Rossminster Ltd [1980] AC 952. Where legislation provided for judicial warrants of search and seizure in tax fraud investigations, Lord Denning held that 'it is ... the duty of the courts so to construe the statute as to see that it encroaches as little as possible upon the liberties of the people of England'. The House of Lords overturned the decision, with Lord Wilberforce concluding that it is the duty of the courts to construe statutes according to their terms. Lord Denning invoked the spirit of John Wilkes and cited Entick, but, ironically, his approach was at odds with Lord Camden's view that: 'The best way to construe modern statutes is to follow the words thereof.'

${ }^{28}$ Lord Denning, Landmarks in the Law (London, Butterworths, 1984) 270-72.

${ }^{29}$ AV Dicey The Law of the Constitution, JWF Allison (ed) (Oxford, Oxford University Press, 2013) 100.

${ }^{30}$ EC Thomas, Leading Cases in Constitutional Law (London, Stevens \& Haynes, 1876).
} 
'landmarks in the vindication of civil liberties'. ${ }^{31}$ Perhaps because of these uses of the case in texts, the decision is cited quite often today. ${ }^{32}$

The citations tend to be rhetorical. Entick has been cited three times by the Justices of the UK Supreme Court since it was inaugurated in 2009. ${ }^{33}$ In re Guardian News and Media Ltd illustrates the rhetorical kind of citation. The Guardian successfully sought the discharge of anonymity orders for terrorism suspects during proceedings in which the suspects were challenging their designation as suspects. ${ }^{34}$ Lord Rodger said:

Not $\mathrm{E}$ but Mr John Entick of Stepney has gone down in history as the plaintiff in the great case of Entick $v$ Carrington (1765) 19 State Tr 1029. ${ }^{35}$

When the citations are not rhetorical, they sometimes treat Entick as a landmark that stands for more than it decided. In Ahmed $v$ Her Majesty's Treasury and Smith $v$ Ministry of Defence, ${ }^{36}$ the Justices referred to principles purportedly established by Entick. In Ahmed, Lord Hope held that Entick supports the proposition that the claimant had a 'right to peaceful enjoyment of his property, which could only be interfered with by clear legislative words' ${ }^{37}$ This approach embellishes Entick, which said nothing about clear legislative words; in Entick, there was no general legislation of the kind that was at issue in Ahmed (in which the Supreme Court held that the United Nations Act 1946 s 1, authorising His Majesty 'to make such provision as appears to Him necessary or expedient' to apply decisions of the UN Security Council, did not authorise provisions that made no provision for procedural fairness).

In Smith v Ministry of Defence, Lord Hope endorsed the view of Elias J in the earlier case of Bici v Ministry of Defence, that 'combat immunity' from actions in tort

\footnotetext{
${ }^{31}$ Carol Harlow and Richard Rawlings, Law and Administration, 3rd edn (Cambridge, Cambridge University Press, 2009) 750.

${ }^{32}$ Five times in the courts of England and Wales in 2013, and five times in 2014: R (Youssef) $v$ Secretary of State for Foreign and Commonwealth Affairs [2013] EWCA Civ 1302 [25]; Rani Poonam $v$ Secretary of State for the Home Department [2013] EWHC 2059 [42]; Malik v Fassenfelt [2013] EWCA Civ 798 [45]; Smith v Ministry of Defence [2013] UKSC 41 [90]; and AKJ and others $v$ Commissioner of Police of the Metropolis [2013] EWHC 32 [71]; Wiltshire v DPP [2014] EWHC 4659 [8]; $R$ (Mills) v Sussex Police [2014] EWHC 2523 [56]; $R$ (Allensway Recycling Ltd) v Environment Agency [2014] EWHC 1638 [35]; Commissioner of Police of the Metropolis v Bangs [2014] EWHC 546 [40]; R (Miranda) v Secretary of State for the Home Department [2014] EWHC 255 [42].

${ }^{33}$ To March 2015.

${ }^{34}$ In re Guardian News and Media Ltd [2010] UKSC 1, [2010] 2 AC 697.

35 [2010] UKSC 1, [67].

${ }^{36}$ Ahmed v Her Majesty's Treasury [2010] UKSC 2 and Smith v Ministry of Defence (n 32).

37 Ahmed (n 36) [75].
} 
...is essentially an exception to the Entick $v$ Carrington principle and as such should be narrowly construed. The courts recognise that very exceptionally the basic liberties of the citizen may have to give way to vital interests of state. ${ }^{38}$

What was the Entick $v$ Carrington principle? In Smith, Lord Hope said that the principle established in Entick was 'that the executive cannot simply rely on the interests of the state as a justification for the commission of wrongs' ${ }^{39}$ Entick did indeed stand for that, but the effect of the decision is greatly embellished, if carelessness by commanders in overseas military operations is taken to be a civil wrong. Breaking into a person's house to take his belongings was a civil wrong in 1765 , if the warrant of the Secretary of State did not authorize it; but it would never have occurred to Lord Camden that the Ministry of Defence could owe a duty of care in tort of the kind that was in issue in Smith, to British soldiers serving overseas. So there is no ground for saying that there would be 'an exception to the Entick v Carrington principle' if (contrary to the conclusion in Smith), the Ministry of Defence had no duty of care in negligence to soldiers engaged in overseas military operations.

But where there is a civil wrong, Entick does at least stand for the proposition that the warrant of the Secretary of State does not legitimize it. It is, in fact, a principle that Lord Camden had established two years before Entick in Wilkes $v$ Wood.$^{40}$ The only material differences I can see between the cases are that Wilkes had not been named in the warrant in his case and that Lord Camden was only instructing a jury as to the law in Wilkes, whereas in Entick, he gave judgment on the law after a special verdict. The arguments in Lord Camden's thrilling instruction to the jury in Wilkes are those of Entick, but with the addition of a flamboyant suggestion-which he can hardly have meant and which he could hardly have used as a basis for a judgment on the law if the issue had been before him - that an Act of Parliament could not authorise a departure from the spirit of the constitution:

He then observed, that the present cause chiefly turned upon the general question, whether a Secretary of State has a power to force persons houses, break open their locks, seize their papers, \&c. upon a bare suspicion of a libel by a general warrant, without name of the person charged. A strange question, to be agitated in these days, when the constitution is so well fixed ... No precedents, no legal determinations, not an Act of Parliament itself, is sufficient to warrant any proceeding contrary to the spirit of the constitution.

... He then congratulated the jury, that they had now in their power the present cause, which had been by so much art and chicanery so long postponed. Seventy years had now elapsed, since the Revolution, without any occasion to enquire into

\footnotetext{
${ }^{38}$ Bici v Ministry of Defence [2004] EWHC 786 [90].

${ }^{39}$ Ibid.

${ }^{40}$ Wilkes $v$ Wood (1763) Lofft 1; 98 ER 489.
} 
this power of the Secretary of State, and he made no doubt but the jury would effectually prevent the question from being ever revived again. He therefore recommends it to them to embrace this opportunity (lest another should not offer, in haste) of instructing those great officers in their duty, and that they (the jury) would now erect a great sea mark, by which our State pilots might avoid, for the future, those rocks upon which they now lay shipwrecked. ${ }^{41}$

So Wilkes $v$ Wood was a sea mark and Entick was a landmark.

Entick established that a warrant specific as to the person fell within the rule that general warrants are unlawful. This change was important; it was a step in the imposition of the rule of law on the British government. And the decision established the law on this point with an authoritative effect that Huckle $v$ Money and Wilkes $v$ Wood did not have, because of the special verdict in Entick: the judge directed the jury to decide the facts, and to assess damages in case the defendants were held liable, but reserved it for the full court to decide the law and its application to the facts. The process facilitated Lord Camden's direct attack on the legal issues. ${ }^{42}$.

But the case's role as a landmark lies not only in that change. The decision has an important role in the wider development of the law. In fact, there are a variety of ways in which the case serves as a landmark. It is a landmark in advocacy. Notice that the key points in Lord Camden's speech had been put forward in the argument of counsel for the plaintiff:

If any such power in a Secretary of State, or a Privy Counsellor, had ever existed, it would appear from our law-books; all the ancient books are silent on this head. ${ }^{43}$

It is the publishing of a libel which is the crime, and not the having it locked up in a private drawer in a man's study. ${ }^{44}$

And if Lord Camden's grand rhetoric does much to explain the fame of the decision, we should give the plaintiff's counsel credit for the same bravura:

[I]f they are held to be legal the liberty of this country is at an end ... this would be worse than the Spanish Inquisition; for ransacking a man's secret drawers and boxes to come at evidence against him, is like racking his body to come at his secret thoughts ... this would be monstrous indeed; and if it were lawful, no man could endure to live in this country. ${ }^{45}$

And there is conversely something poignant in the eloquence of the opening statement of counsel for the defendants:

\footnotetext{
${ }^{41}$ ibid 3-4.

${ }^{42}$ See Tom Hickman's chapter in this volume for a nuanced account of the legal effect of the decision.

${ }^{43}$ (1765) 2 Wils KB 275, 286.

44 ibid 282.

45 ibid $282-83$.
} 
I am not at all alarmed, if this power is established to be in the secretaries of state. ${ }^{46}$ Here is the classic picture of the advocate as officer of the court: for him to say that he is not alarmed, as if it is something worth mentioning to the Court, is to presuppose that he is not a mere mouthpiece for the defendants, but someone who comes to sober judgment, independent of the judgment of his client, on the points of law on which he advises the Court. Entick is a landmark in the development of the complex role of the common law barrister as advocate, and yet as independent.

And within Lord Camden's reasoning, I think that Entick also stands as a landmark in the developing doctrine of statutory interpretation. Lord Camden had a pithy recommendation for statutory interpretation in the modern world:

The best way to construe modern statutes is to follow the words thereof. ${ }^{47}$ Lord Camden was not being clever; he meant to propose his method of construction to be chosen over alternatives that might be chosen (and that might rightly have been chosen in respect of construction of more ancient statutes). ${ }^{48}$

I mention this just to point out the multifarious fruitfulness of Lord Camden's decision, but I will focus on the doctrine of the powers of public authorities, as it is of course the nub of the decision.

\section{The Powers of Public Authorities and the Ancient Venerable Edifice}

Where do public powers come from in the English constitution? It is not easy to find a source in the sense of a starting point. Even the Duke of Normandy claimed a lawful right of succession to the throne of England (allegedly promised to him by Edward the Confessor) when he invaded in 1066, conquered Harold II's army and killed him, laid waste to the north, and subjugated England. To a chaotic, decentralised country, French Vikings brought a simple administration and an effective military. They ruled on the basis of a continuity of royal authority, not much constrained by the rather indeterminate traditional role of assemblies of leading men under the Anglo-Saxons, but certainly constrained by understandings (doubtless under-theorised understandings) of responsibility to the people

\footnotetext{
${ }^{46}$ ibid 283.

47 ibid 290.

${ }^{48}$ Counsel for the defendants put the alternative to him: 'Supposing there is a defect of jurisdiction in the Secretary of State, yet the defendants are within the stat. 24 Geo. 2, c. 44, and though not within the words, yet they are within the reason of it; that it is not unusual in Acts of Parliament to comprehend by construction a generality where express mention is made only of a particular': ibid 284 .
} 
(or at least to the barons) and to God. The king's powers were closely constrained in some respects by feudal relations, but were not articulated in any act of constitution making, and the limits of those powers were not enforced by any separation of state powers. The king's power was far from absolute-no one imagined that he had authority to enslave his barons-but it was unspecific. He held his authority as a king to act for the good of the kingdom and as a ruler under God, and not for his own gratification. But there was no state apparatus, and no law, to secure the king's adherence to his duty to act for the good of the kingdom.

In order to secure revenue, the king needed to keep the barons relatively happy in general, and in particular he needed to consult them about taxes. Those needs evolved into duties, as kings promised the barons from time to time that they would do right, ${ }^{49}$ and as the King's Council developed specialisations that became courts of law and a specialisation that became Parliament, and as Parliament acquired a House of Commons and evolved into a constitutional legislative authority. ${ }^{50}$ In addition to those duties, it had all along been the king's duty to administer justice.

The Plantagenet kings discharged their duty to legislate responsibly by legislating in Parliament, and they discharged their duty to administer justice by delegation to their judges. They sent out judges to administer justice according to law in the king's name; in a stroke of accidental genius, they did not tell the judges what the law was, but gave them authority to issue writs in the name of the king (a technique that had been missing in Normandy). The power to issue writs to sheriffs in the king's name gave the judges not merely a jurisdiction to resolve disputes, but a constitution-building authority that they used, eg, to construct habeas corpus ad subjiciendum as a control on arbitrary detention (at first, against local authorities including local courts). Legislative and judicial powers became separated gradually from the rest of the power of the king, until Sir Edward Coke was able to hold-as the king's judge, in the king's name-that the king could not decide judicial cases personally, but only through his judges, ${ }^{51}$ and that the king had no authority to create

\footnotetext{
${ }^{49}$ As in Henry I's coronation charter in 1100 or John's Great Charter.

${ }^{50}$ See JH Baker, An Introduction to English Legal History, 3rd edn (London, Butterworths, 1990) 234 39.

${ }^{51}$ Prohibitions del Roy (1607) 77 ER 1342; 12 Co Rep 64. 'His Majesty was not learned in the laws of his realm of England, and causes which concern the life, or inheritance, or goods, or fortunes of his subjects, are not to be decided by natural reason but by the artificial reason and judgment of law, which law is an act which requires long study and experience, before that a man can attain to the cognizance of it: that the law was the golden met-wand and measure to try the causes of the subjects; and which protected His Majesty in safety and peace: with which the King was greatly offended, and said, that
} 
offences or to change the common law without an act of Parliament. ${ }^{52}$ These separations of legislative and judicial power from the king's own personal rule were not new with Coke; the two ideas, separating the legislative and the judicial power from the king's own rule, had both been asserted by John Fortescue in the 1460s, and were not new then. ${ }^{53}$ But they were not fully established in Fortescue's time or in Coke's. That took major legislative acts of constitution building by Parliament, including the Habeas Corpus Act 1640, the Bill of Rights 1689 (protecting the privileges of Parliament and outlawing taxation without Parliamentthough that had been widely viewed as constitutionally unacceptable since the reign of Edward III), and the Act of Settlement 1701 (protecting judicial independence by tenure in office that was secure against the Crown).

This constitution had not reached this point by defining three branches of government, but by defining the judicial and legislative roles, and creating new institutions for their discharge. Judicial and legislative institutions began as courts within the court of the king. They emerged as independent high courts with specified powers and were protected against interference from the Crown, with the judges acting in the name of the king, and the king legislating in Parliament. The royal power in general was undefined; the judicial and parliamentary powers came to be defined and to be established as exclusive to the judicial and parliamentary institutions.

Long before the Glorious Revolution and the Act of Settlement, the constitution had included the role of Parliament and the authority of the common law courts. The constitution was dynamic, and had evolved and was evolving when Entick $v$ Carrington was decided. As a constitution in recognisable form, to which Lord Camden could appeal for justification for his decision, it was perhaps 500 years old or so-its roots were certainly more distant from Entick $v$ Carrington than Entick $v$ Carrington is from us. It was, of course, roughly as old as the common law. Lord Camden relied on its antiquity:

[T] he common law did not begin with the Revolution; the ancient constitution which had been almost overthrown and destroyed, was then repaired and revived; the Revolution added a new buttress to the ancient venerable edifice. ${ }^{54}$

then he should be under the law, which was treason to affirm, as he said; to which I said, that Bracton saith, quod Rex non debet esse sub homine, sed sub Deo et lege [That the King ought not to be under any man but under God and the law].'

${ }_{52}^{52}$ Case of Proclamations (1611) 77 ER 1352; 12 Co Rep 74.

${ }^{53}$ Sir John Fortescue, De Laudibus Legum Angliae, trans A Amos (London, Butterworth, 1825), available at http://archive.org/details/delaudibusleguma00fortuoft.

${ }^{54}$ (1765) 2 Wils KB 275, 292. 
Various further advances were being achieved at the time of Entick in the development of relations among the legislature, the judiciary and the executive; perhaps the most important in principle and in practice are the accountability of the ministers of the Crown to the House of Commons, and the convention that the monarch assents to legislation approved by both Houses, and acts on the advice of his or her ministers. More recent, and very important in principle, is the development of the judges' power to act in the name of the Queen to remedy and to prevent abuse of the prerogative by the Queen's ministers, developed in a series of cases centred on $R v$ Criminal Injuries Compensation Board ex $p$ Lain $^{55}$-a decision that Lord Scarman called 'a landmark case comparable in its generation with the Case of Proclamations'. ${ }^{56}$ These are significant changes, and yet the ancient venerable edifice is still recognisable in 2015. In 2015, the UK has the Plantagenet constitution, with various important amendments:

- It is now the constitution of the United Kingdom.

- The judges cannot be dismissed by the Crown.

- The Queen's ministers must have the confidence of the House of Commons.

- The Queen must act on the advice of her ministers and must assent to legislation approved by both Houses of Parliament.

- The Members of Parliament in the Commons are elected by universal suffrage, and all adult citizens are eligible for election to the House of Commons or appointment to the House of Lords.

- The Commons have achieved ascendancy over the Lords rather broadly by convention and have specific legal powers to legislate against the will of the Lords.

And there have been other amendments, of course. But in general terms, the source of public powers is the same in 2015 as it was 800 years ago.

What was the source of public powers in the ancient venerable edifice? The king had authority under God for the government of the realm. The extent of his authority was not defined, although many instances and aspects of it were perfectly well understood. ${ }^{57}$ And he held his undefined authority not for his own pleasure, but in his responsibility for the peace, order and good government of the realm. He had what power was appropriate to the discharge of that responsibility, he discharged his responsibility to do justice according to law through his judges and he made laws for the realm in Parliament. His ministers, agents

\footnotetext{
${ }^{55} R$ v Criminal Injuries Compensation Board ex p Lain [1967] 2 QB 864.

${ }^{56}$ Council of Civil Service Unions v Minister for Civil Service [1985] AC 374, 407.

${ }^{57}$ Blackstone used the technique of explaining the prerogative by reference to examples, starting with 'the right of sending ambassadors, of creating peers, and of making war or peace' and proceeding with several others. Sir William Blackstone, Commentaries on the Laws of England, with notes by George Sharswood (Philadelphia: J.B.Lippincott, 1893) Book I, Chapter VII, p 240.
} 
and servants had authority under him for pursuing the public purposes for which they were given authority, and had no authority to act contrary to statute or to the common law.

I will call this the 'positive conception' of the powers of public authorities. While it involves - needless to say - an extraordinarily simplistic truncation of the more sophisticated conclusions that we would draw from a proper understanding of more than 1,000 years ${ }^{58}$ of constitutional history, I think it is roughly accurate. And I will defend it as a conception of the powers of public authorities that is potentially a part of a healthy, balanced constitution. You may say that it is a royalist view, suiting Blackstone and perhaps Mansfield, but at odds with the go-ahead attitudes of Lord Camden. I will argue to the contrary that it is the conception of public powers that informs Entick $v$ Carrington. This is a surprisingly hard argument to make. The argument has to deal with the attractions of a different, negative conception.

\section{A. The Negative Conception of Public Powers}

The rule of law, according to Adam Tomkins:

[P]rovides that the executive may do nothing without clear legal authority first permitting its actions... Whereas the rule of law provides that the executive may do nothing without clear legal authority, individuals may conversely do anything unless expressly prohibited by law. Authority for these propositions is contained in the seminal common law case, Entick v Carrington. ${ }^{59}$

Tomkins has other leading lights of public law -in the academy and on the bench-on his side. In $R v$ Somerset County Council ex $p$ Fewings, ${ }^{60}$ Lord Justice Bingham had the following to say to a local authority in respect of its ownership of land:

[I]t is not lawful for you to do anything save what the law expressly or impliedly authorises. You enjoy no unfettered discretions. There are legal limits to every power you have.

Mr Justice Laws had held at first instance that:

For private persons, the rule is that you may do anything you choose which the law does not prohibit ... But for public bodies the rule is opposite, and so of another

\footnotetext{
${ }^{58}$ I say this because although there was a deep discontinuity in the exercise of public authority in 1066 , there was not such a deep discontinuity in the principles on which the rulers based their justifications for its exercise. A good deep understanding of the English constitution in 1765 would involve an understanding of its roots before 1066 .

${ }^{59}$ A Tomkins, Public Law (Oxford, Oxford University Press, 2003) 78.

${ }^{60} R v$ Somerset County Council ex p Fewings [1995] 3 All ER 20 at 25.
} 
character altogether. It is that any action has to be taken must be justified by positive law. ${ }^{61}$

And Paul Craig is of a similar view:

A core idea of the rule of law to which all would subscribe is that the government must be able to point to some basis for its action that is regarded as valid by the relevant legal system. Thus in the UK such action would commonly have its foundation in statute, the prerogative or in common law power ... If the government cannot provide a legal foundation for its action then the UK courts would regard this action as unlawful, since there would be no lawful authority for it. ${ }^{62}$

I will call this the 'negative conception' of public powers: no such powers exist unless they have been specifically conferred by law.

Contrast this negative conception with the positive conception: that public authorities have undefined, open-ended, inherent powers to carry out their own appropriate role for the public good unless such a power is specifically taken away by law.

I think we should prefer the positive view as an account of the sources of public power in 2015. My reasons for rejecting the negative view are not only that it is against the English genius-instanced in the common law-for dealing with matters as they arise, in a pragmatic fashion, rather than trying to give prior authorisation to everything that ought to be authorised. There are other reasons, which are as follows.

\section{i. Entick Does Not Support the Negative Conception}

Contrary to Tomkins' claim about Entick, there is no authority in Lord Camden's decision for the proposition that the executive may do nothing without clear legal authority. The decision is only authority for the proposition that the executive cannot assert a defence to a claim in trespass without clear legal authority. This is not pettifogging; it is absolutely essential to remember that in Entick, the defendants were liable in trespass unless the sayso of the Secretary of State lawfully authorised the entry into Entick's house and the taking of his property.

We should agree with Tomkins, on the other hand, that it would be a crude misunderstanding of Entick to think of it as based merely on a doctrine of protection of

\footnotetext{
${ }^{61}$ The Council had banned hunting on its land on the ground that it was cruel to animals; Laws J held that they had based their decision on a consideration that was irrelevant to the proper exercise of their powers; the Court of Appeal upheld the ruling on the narrower ground that the Council had not considered its statutory duty promote the benefit of the area.

${ }^{62}$ Constitution Committee, Relations between the Executive, the Judiciary and Parliament (HL 200607, 151) 98 .
} 
property. It is not that Lord Camden did not hold that the law protected Entick's real and personal property; he certainly did hold that. But his reasons for the protection of property very clearly concern a person's interests in privacy, and in liberty of thought and expression. There was, in particular, something special about papers:

Papers are the owner's goods and chattels: they are his dearest property; and are so far from enduring a seizure, that they will hardly bear an inspection; and though the eye cannot by the laws of England be guilty of a trespass, yet where private papers are removed and carried away, the secret nature of those goods will be an aggravation of the trespass, and demand more considerable damages in that respect. ${ }^{63}$

So the case was not decided on an unreasoned preference for property owners. But it was most certainly not decided on the basis that a public authority can do nothing unless the thing is expressly or impliedly authorised by law. Lord Camden did not decide that state authorities can only do what the law authorises them to do; he decided that state authorities have no defence to the tort of trespass that the law does not give them.

No man can set his foot upon my ground without my license, but he is liable to an action, though the damage be nothing ... If he admits the fact, he is bound to show by way of justification, that some positive law has empowered or excused him. The justification is submitted to the judges, who are to look into the books; and if such a justification can be maintained by the text of the statute law, or by the principles of common law. If no excuse can be found or produced, the silence of the books is an authority against the defendant, and the plaintiff must have judgment. ${ }^{64}$

The silence of the books does not mean that a secretary of state, or his henchmen, cannot do anything. The principle in Entick is not that the interests of the state cannot justify action by a public authority that has not been expressly or impliedly authorised by law. Instead, the principle is as Lord Hope put it in Smith v Ministry of Defence: that the interests of the state are not 'a justification for the commission of wrongs'. ${ }^{65}$

Incidentally, it is not just that Lord Camden did not happen to say anything in support of the negative conception in Entick; he would have dissented from it, as Christopher Vincenzi showed:

It remained unclear following Entick $v$ Carrington whether acts of government which were not specifically authorised by common law were only unlawful if they interfered directly with an existing personal or proprietorial right. Lord Camden

\footnotetext{
63 (1765) 19 St Tr 1029, 1066.

${ }^{64}$ ibid. It is rather figurative to say that the silence of the books is an authority against the defendant; Lord Camden meant that if there is an entry to or taking of property without the consent of the owner, the entry or taking is prima facie a trespass, and will be conclusively held to be a trespass unless the defendant shows the lawfulness of the entry or taking.

${ }^{65}$ Smith v Ministry of Defence (n 32) [90].
} 
evidently thought so, for the following year he advised the government that it could, without legislation, prohibit the export of wheat by proclamation. ${ }^{66}$

So Lord Camden was against the negative conception. The negative conception may be sound, you will say, even if Entick is not authority for it, and even if Lord Camden did not share it. But there are other reasons against it.

\section{ii. History is against the Negative Conception}

I do not see how to reconcile the negative conception with the Plantagenet constitution. So much the worse for Plantagenet constitutional law, you may say (and I suppose there are some people who would fall into the mistake of saying that there was no constitutional law under the Plantagenets). But now, if you suppose that the negative conception is a sound understanding of public powers in 1765 or 2015, there is a problem: when did the constitution switch polarity, from the positive conception under which the Crown (and, I think, other public authorities too) had unspecified powers that were limited by law, to the negative conception under which no state authority has the power to do anything unless it is specified by law? Under the Commonwealth perhaps? But if so, the polarity was reversed again 10 years later, when the Restoration proceeded on the ground that Charles II had been King since Charles I was beheaded. In the Glorious Revolution? But the Bill of Rights 1689 did not specify the powers of the executive. Its purpose was that the Lords and the Commons 'might not againe be in danger of being Subverted', and it was enacted 'for the Vindicating and Asserting their auntient Rights and Liberties'. It was, as Lord Camden described it, the addition of a buttress to the ancient venerable edifice. It specified things that the executive could not do, and it presupposed the executive's unspecified authority to act for the good of the kingdom. After all, they were declaring William to be a king:

[T]o hold the Crowne and Royall Dignity of the said Kingdomes and Dominions ... And that the sole and full Exercise of the Regall Power be onely in and executed by the said Prince of Orange.

The real, material change in the constitution was not in 1689, but came only as the convention developed that the monarch had to act on the advice of ministers who could only hold office while they had the confidence of the House of Commons. Of course, the country was propelled into that transformation towards more responsible government by the fact of the Glorious Revolution. It was understood on all sides that the King was there because the parliamentarians wanted him there, and that the basis of his reign was to be

${ }^{66}$ C Vincenzi, Crown Powers, Subjects and Citizens (London, Pinter, 1998) 11-12. 
different from what the Stuarts had envisaged. But the Glorious Revolution did not guarantee responsible government; this was accomplished in the day-to-day operation of government only over the following two centuries and more. At no point in that development do we have any reason to say that the basis of public power reversed its polarity. The negative conception of public powers is not something that can gradually evolve. Since 1689, the Crown has gradually become accountable to the representatives of the people for all aspects of the use of its powers, and to the courts for the lawfulness of its use of powers. New limits have been imposed on public powers, and new controls have been imposed on their exercise. But there was never a point at which it became the case that the law exhaustively specified the powers of the Crown, or the powers of other public authorities.

iii. The Negative Conception Would Not Advance the Purpose of Securing Responsible Government

After the Civil War, the Instrument of Government of 1653, you might say, really did adopt the negative conception. It defined the executive power. The parliamentarians did not (at that point) want a king, so they made the Lord Protector 'chief magistrate', and stated that he would have authority over the exercise of administration of government. ${ }^{67}$ The arrangement got them the chief executive whom they wanted. If the Instrument had been lawfully adopted, the Lord Protector would have had clear legal authority permitting his actions. But that would not have achieved the purpose of the negative conception of public power, which, as Tomkins points out, is to give substance to the rule of law. Express conferment of general executive power is no more specific than going on with a monarch with unspecified executive power.

The US, though, had a more gifted class of constitution framers. They did a better job of the specification, not simply providing (in Article II of their new Constitution) that the executive power shall be vested in a President of the United States of America', but listing the responsibilities of the President (basically, command of the military, general oversight of the executive departments of government, granting reprieves and pardons, making treaties by and with the advice and consent of the Senate, and nominating ambassadors, Supreme Court justices, and other officers of the US). But it may be no surprise to learn that, from

\footnotetext{
${ }^{67}$ Article II: 'the exercise of the chief magistracy and the administration of the government over the said countries and dominions, and the people thereof, shall be in the Lord Protector'.
} 
Alexander Hamilton and James Madison to the Supreme Court Justices today, ${ }^{68}$ Americans have argued both about the nature and extent of the enumerated powers, and about whether the vesting of the 'the executive power' involves general unspecific authority (with the enumerated powers as instances) or whether the enumerated powers are exclusive. Some have thought that the negative conception of public powers offers the best interpretation of their constitution, but the US Supreme Court has held that 'Article II grants to the President the executive power of the Government, i.e., the general administrative control of those executing the laws' ${ }^{69}$ The US Constitution did a much better job than the English Protectorate's Instrument of Government, both in specifying executive powers and in limiting them. But it would be rather meaningless to say that the US President may do nothing without clear legal authority first permitting his actions, because the unclarities are dramatic in the executive power of the government he leads.

I do not think that either the Instrument of Government or the US Constitution were defective, merely by virtue of the open-endedness of the executive powers they established, because it seems to me that the open-endedness is necessary in the public interest. If a constitution sets out to specify the powers of the executive, it must do so in wide open terms. Such a constitution might protect persons from the abuse of power (as the US Constitution does in various ways), but it would not be able to do so by setting out a specification of the powers of the executive, because it would not be possible to specify those purposes in a way that would constrain the officials while also enabling them to do what is worth doing in the public interest.

You may still think that the positive conception is medieval in the pejorative sense, is too cavalier, and is not conducive to limited government. The negative conception may seem to follow simply from the proposition that the king is under the law. But it does not. Blackstone went along with the traditional English view that: 'It is a maxim of the English law, as we have seen from Bracton, that "rex debet esse sub lege, quia lex facit regem". ${ }^{70}$ But he was in favour of the positive conception of public powers. And he quoted Sir Henry Finch, writing in the time of Charles I:

\footnotetext{
${ }^{68}$ For an overview, see the 'Annotated Constitution', prepared by the Congressional Research Service of the Library of Congress: www.law.cornell.edu/anncon/html/art2toc_user.html. The latest decision on the scope of the President's executive power is National Labor Relations Board v Canning, US Supreme Court, No 12-1281, 26 June 2014.

${ }^{69}$ Myers v US 272 US 52 (1926) 163-64.

${ }^{70}$ Blackstone, Commentaries (n 57) Book I, Chapter VII, p 238.
} 
'The king hath a prerogative in all things, that are not injurious to the subject; for in them all it must be remembered, that the king's prerogative stretcheth not to the doing of any wrong.'

On the positive conception, the king is under the law, and so: (1) the executive branch of government (like the other branches) may not act contrary to law; (2) Parliament may take executive powers away by law; and (3) disputes as to the nature and extent of executive powers, or complaints of abuse of those powers, may in a proper case be determined with binding effect by the courts. That is enough for the rule of law.

The negative conception may seem to be a constitutional essential, because without it, state necessity-or even just state interests-will be used as a pretext for irresponsible government. If public authorities have unspecified powers to pursue public goods, that seems to play right into the hands of counsel for the defendants in Entick, who argued that the Secretary of State had to be able to take on the power he claimed in order to protect the security of the state. But although they assumed the positive conception of public powers, Lord Camden and Sir William Blackstone both rejected the notion that state necessity justified uncontrolled executive powers-Lord Camden in Entick and Blackstone in his account of judicial review of administrative action in the Court of King's Bench. In his stirring account of the role of the King's Bench in restraining arbitrary use of power, Blackstone related that the Privy Council had ordered that no actions should be entertained in the courts against the Commissioners of Sewers:

[I]n the reign of king James I, (8 Nov. 1616,) the privy counsel took upon them to order that no action or complaint should be prosecuted against the commissioners unless before that board; and committed several to prison, who had brought such actions at common law, till they should release the same: and one of the reasons for discharging Sir Edward Coke from his office of lord chief justice was for countenancing those legal proceedings. The pretence for which arbitrary measures was no other than the tyrant's plea of the necessity of unlimited powers in works of evident utility to the public, 'the supreme reason above all reasons, which is the salvation of the king's lands and people'. But now it is clearly held, that this (as well as all other inferior jurisdictions) is subject to the discretionary coercion of his majesty's court of king's bench. ${ }^{71}$

In the ancient venerable edifice, the king's ministers had an open-ended, discretionary jurisdiction to act for the protection and the good governance of the realm, subject to the constraints that the law imposed on them. And the courts had an open-ended, discretionary jurisdiction, in the name of the King, to stand against the arbitrary use of executive power.

\footnotetext{
${ }^{71}$ Blackstone, Commentaries (n 57), Book III, Chapter VI, p 74.
} 
And it was and is contrary to the principles of the constitution to take that power away from the court.

There are the most pressing reasons to have a constitution that does what a constitution can to prevent abuse of power. There is no reason to have a constitution that says that executive officials have no powers that are not bestowed on them by law. Paul Craig says that 'it is a core idea of the rule of law to which all would subscribe ... that the government must be able to point to some basis for its action that is regarded as valid by the relevant legal system'; I think it is enough (for the rule of law in general and for the principle of Entick) if the government can show that the basis of its action is not regarded as unlawful by the relevant legal system.

Let me close with one irony concerning the negative conception: I think that it is alien to what Lord Camden called 'the spirit of the constitution' (Wilkes $v$ Wood), because it sets up a distinct law for state authorities. Lord Camden treated the Secretary of State no differently from any private person who directs another to enter a home and seize papers. I suppose that on the negative conception of public powers, the seizure of Entick's papers by public servants was unlawful because no law clearly authorised it, whereas the seizure of his papers by a burglar acting in his private capacity would have been unlawful because there was a law prohibiting the trespass. As Mr Justice Laws put it, on the negative conception of public powers, 'for public bodies the rule is opposite, and so of another character altogether'. Lord Camden pointed out, just as he was coming to his conclusion in Entick, that:

Serjeant Ashley was committed to the Tower in the $3 \mathrm{~d}$ of Charles $1^{\text {st }}$, by the House of Lords only for asserting in argument, that there was a 'law of state' different from the common law. ${ }^{72}$

\footnotetext{
${ }^{72}$ See A Thrush and JP Ferris (eds), The History of Parliament: The House of Commons 1604-1629 (Cambridge, Cambridge University Press, 2010), s.v. Ashley, Francis: 'According to Sir Edward Coke, he presented "five damnable and desperate reasons" for rejecting the Commons' arguments, the gist of his case being that any constraints on royal power would result in anarchy. This extreme position offended both Commons and Lords, and he was censured and temporarily suspended from the Upper House until he acknowledged his offence at the bar.' I take it, incidentally, that there is an error in the Wilson report, which says: 'Sir Samuel Astry was committed to the Tower, for asserting there was a law of State distinct from the common law' (292). Perhaps there had been a typographical error, or perhaps Wilson did not know of Francis Ashley, and erred by attempting to make a correction: there was a Sir Samuel Astry (1632-1704) who was a clerk of the Privy Council under James II: Harriet Blodgett, 'Astry, Diana (bap. 1671, d. 1716)' in Oxford Dictionary of National Biography (Oxford, Oxford University Press, 2005). This form of allusion was a special trope of Lord Camden's: $c f$ his statement in Wilkes $v$ Wood (n 40) that 'Secretary Williamson, in Charles the Second's time, for backing an illegal warrant, was sent to the Tower by the House of Commons'.
} 
I am not proposing that such any such measure ought to be taken against the scholars and judges who say that the legal position of public authorities is the opposite to that of natural persons (or, presumably, of private corporate bodies). But we should agree with Lord Camden that, even in 2015 , there is no 'law of state' different from the common law that makes a private individual or corporation, and public authorities, liable in trespass.

\section{Conclusion: Change in the Common Law}

Did Lord Camden see himself as establishing a landmark? He must have: he had challenged the jury in Wilkes to establish a 'sea mark' to warn state officials away from the rocks; he knew, needless to say, that it was a big deal politically-'of the utmost consequence to the public ${ }^{73}$ - but also legally:

I desire that every point of this case may be argued to the bottom; for I shall think myself bound, when I come to give judgment, to give my opinion upon every point in the case. ${ }^{74}$

But he was careful to present his decision as based on the ancient venerable edifice of the constitution, and not as new build. The genius of Lord Camden's judgment in Entick lies in his appeal to the ancient constitution as a justification for the undeniably new rule that the King's ministers could not lawfully authorise a search for evidence of seditious libel. His disregard of an established custom of arbitrary searches was artful:

We shall now consider the usage of these warrants since the Revolution; if it began then, it is too modern to be law; the common law did not begin with the Revolution. ${ }^{75}$

And his assertion of judicial modesty was artful:

If the king himself has no power to declare when the law ought to be violated for reason of state, I am sure we his judges have no such prerogative. ${ }^{76}$

The positive conception of public powers means that we need active, creative judges. But they can engage creatively in law making-and in constitution making - while seeking to give effect to ancient principles. There is a value in this approach, which is to temper the judges' potentially unruly or willful search for justice, with the continual discipline of searching for a

\footnotetext{
73 (1765) 2 Wils KB 275, 286

74 ibid.

75 ibid 292

76 (1765) 19 St Tr 1029, 1073.
} 
rationale for what they seek to achieve, which is detached from their own impulses. It is a discipline that they can adopt without losing any of their independence.

The common law's specific mode of change involves a presupposition of continuity. So it may seem paradoxical, and yet I think that it is not surprising that in a great landmark case that is being cited by the highest court in this country and others 250 years after the decision, the reasons were ancient. That is, in fact, the distinctive way in which the common law changes. 